\title{
Does Existence of Long-Run Relationship Ensure Predictability of Exchange Rate? Empirical Analysis of Indian Rupee Vis-à-Vis US Dollar under Monetary Model Framework
}

\author{
Vaishali Padake1, Bhargavi Karamcheti1, T. Geetha ${ }^{2}$ \\ ${ }^{1}$ K. J. Somaiya Institute of Management Studies and Research, Mumbai, India \\ 2Jankidevi Bajaj Institute of Management Studies, Mumbai, India \\ Email: vaishali.padake@gmail.com
}

Received 17 May 2016; accepted 14 June 2016; published 17 June 2016

Copyright (C) 2016 by authors and Scientific Research Publishing Inc. This work is licensed under the Creative Commons Attribution International License (CC BY). http://creativecommons.org/licenses/by/4.0/

(c) (i)

\section{Abstract}

This paper examines the empirical relevance of the flexible price monetary model in the Indian context to determine whether US dollar-Indian rupee exchange rate movements are in line with the changes in monetary fundamentals namely relative money supply, relative interest rates and relative output. A sample period of nineteen years (August 1996 to March 2015) was considered for the study and the entire period was divided into two sub periods marked by distinct patterns of exchange rate volatility and variations in the behaviour of macro-economic fundamentals. The study examined whether there exists a long-term relationship between exchange rate and variables of the monetary model besides investigating the predictive ability of the model in determining the exchange rate in the Indian context. The Johansen Juselius test of cointegration was carried out and the variables were found to be linearly cointegrated establishing the long-run relationship between exchange rate and monetary fundamentals rate thereby confirming the suitability of the flexible price monetary model in determining Indian rupee vis-à-vis US dollar. The Granger causality test [21] was conducted to determine the direction of causality between variables and to evaluate the predictive power of the monetary model and the test results exhibited some idiosyncratic patterns among the variables across the two sub periods. For the first sub period, the Granger causality test results show that there is a one-way causality from relative output and relative money supply to exchange rate, while there is no causality from relative interest rate to exchange rates. This result is quite puzzling and calls for further investigation. As the direction of causality is changing within the sample, the study suggests that the monetary model standalone cannot be effectively used for predicting exchange rate in the Indian context. A more comprehen- 
sive model with more macro economic variables such as trade balance and capital flows may be combined with the existing variables for effective forecasting of exchange rate in India.

\author{
Keywords
}

\author{
Exchange Rate, Monetary Model, Cointegration, Granger Causality, Indian Rupee
}

\title{
1. Introduction
}

In an increasingly globalised world, with the growing significance of international trade, the exchange rate has become an important variable impacting the decisions of exporters, importers, bankers, financial institutions and policymakers alike across both the developed and developing world. Since fluctuations in exchange rate have significant implications for a country's business cycles, its trade and capital flows, timely forecasts of exchange rates have become crucial in the spheres of international finance, trade and policy making.

Over the past three decades, in the area of international finance, various theoretical models have been developed and tested to analyse exchange rate behaviour. The liberalisation and development of foreign exchange and assets markets, have led to the consideration of important variables such as capital flows, volatility in capital flows and forward premium along with central bank intervention in determining exchange rates. Furthermore, the micro level dynamics in foreign exchange markets has gained prominence due to rise in the trading volumes in these markets and the subsequent evolvement of the microstructure theory in determining exchange rates (Evans and Lyons, [1] [2]).

The main objective of this study is to empirically assess the long-term relationship between the US dollar-Indian rupee exchange rate and economic variables of the flexible price monetary model of exchange rate to determine whether exchange rate movements are in line with economic fundamentals. Though there is ample research on modelling exchange rate for advanced countries, studies based on emerging countries are confined to a few recent studies. The study therefore focuses on studying the validity of the flexible price monetary model during a managed float exchange rate regime to answer the following two main research questions.

1. Is there a long-term relationship between exchange rate and variables of the monetary model in the Indian context?

2. Can the flexible price monetary model be used to predict exchange rate movements in the long run?

The organisation of the study is as follows: Section 2 provides an historical overview of the exchange rate regimes in India. A review of literature is conducted in Section 3. The theoretical framework is laid out in Section 4. Section 5 enumerates the data sources and methodology of the study. The findings of the analysis are discussed in Section 6 and the final section underlines the conclusions.

\section{Overview of the Exchange Rate Regimes in India}

In the post independence period, India's exchange rate policy has undergone a paradigm shift from a par value system to a basket-peg and further to its current managed float exchange rate system. The Indian rupee which was linked with the pound sterling in the aftermath of the breakdown of the Bretton Woods System in 1971, began to be pegged to a basket of currencies from 1975 till the early 1990s to ensure stability of the exchange rate. Throughout the 1980s, the exchange rate was allowed to fluctuate in a wider margin and to depreciate modestly. However, in the wake of the balance of payment crisis in 1991 and the increasing current account deficit, the Indian economy initiated a number of economic measures to instill confidence in the investors and to improve domestic competitiveness. To offset the substantial draw down in the foreign exchange reserves, the Reserve Bank of India (RBI) had to devalue the Rupee in two stages on July 1 and July 3, 1991 which led to the beginning of a new dual exchange rate regime known as Liberalized Exchange Rate Management System (LERMS). The new regime was implemented from March 1992. Subsequently, the dual exchange rate system LERMS was replaced by a unified exchange rate ushering in an era of market determined exchange rate since March 1993. Reserve Bank of India continued to intervene in the foreign excess market to address instances of volatility making exchange rate regime to be a managed floating exchange rate system. However, going forward, on a more cautious note it may be noted that with India getting increasingly integrated with the world economy and advancing towards full capital 
account convertibility, the management of volatility is likely to be challenging requiring strategic liquidity management to mitigate the associated risks.

\section{Review of Literature}

The switch to floating exchange rates in the 1970s resulted in a wealth of theoretical literature to explain the high volatility in exchange rates. Prior to the 1970s, in an era of fixed exchange rate regimes, many countries adopted the purchasing power parity model (PPP) to study exchange rate behavior. However, in the early 1970s, with the collapse of the fixed exchange rate systems, monetary models of exchange rate determination became popular in modelling exchange rate behavior especially with many of the industrialized economies adopting the floating exchange rate regimes. This section selectively examines some of the most influential structural models that have been developed to model exchange rate behavior.

In the monetary model, it is the money supply in both domestic and foreign countries as opposed to money demand function that determines the exchange rate. Monetary models are the offsprings of the Mundell-Fleming type of models. Several versions of the monetary model have been put forth and prominent among them are Frenkel's [3] flexible price model and the sticky price model developed by Dornbusch [4]. The main underlying assumption of the flexible price model is that prices are perfectly flexible, so that changes in domestic money supply would bring about changes in the domestic price level, as a result of which the domestic currency may appreciate or depreciate as the situation may warrant, to discretely equalise the prices in the two countries. A significant inference from this model is that the PPP holds both in short run and the long-run. This implication came under criticism and the sticky price model was developed by Dornbusch [4] by relaxing the assumption of short-term PPP while holding the long-term PPP assumption and considered price rigidities in modelling exchange rate.

Over the last four decades, the empirical performance of the monetary models has shown mixed results. The academic interest in monetary models began to fade with the seminal work of Meese and Rogoff [5], who concluded that naïve random-walk model outperform out-sample forecast performance of any monetary model at one to twelve month horizons for three major bilateral rates, i.e., the dollar/pound, dollar/mark, dollar/yen and trade weighted dollar exchange rates. On the contrary, some studies such as Mark and Sul [6] who studied the long-run relationship between nominal exchange rates and monetary fundamentals and ability of monetary model in predicting exchange rate found that the nominal exchange rate is cointegrated with monetary fundamentals and that the monetary fundamentals contain significant predictive power for future exchange rate movements. Zhang, Lowinger and Tang [7] too tested the monetary model to examine the long-run relationship as well as short run dynamics for US dollar against Canadian dollar, Japanese yen and British pound and found the existence of a long run relationship between exchange rate and monetary model variables.

Abhyankara, Sarno and Valenteb [8] through their study examined why monetary models performed poorly than random naïve model and observed that most the literature analyzed the model using statistical technique to measure the forecasting accuracy of the model. Their findings suggest that the monetary fundamental models affect the exchange rate both quantitatively and qualitatively and support the predictive power of the monetary model.

In the emerging economy context, many researchers have extended the monetary model of exchange rate determination to these economies having a managed floating exchange rate system. By using Johansen Juselius Autoregressive Distributed Lag (ARDL) techniques, Alao, Oziegbe, Ibidapo, \& Sharimakin [9] and Olaniyi [10] studied the monetary model of exchange rate determination in Nigeria and found that there exists long run relationship among the exchange rate and the variables under monetary model framework. In a similar study, Bruyn, Gupta, \& Stander [11] examined the long run relation between South African Rand and US dollar for the period starting from 1910 till 2010 and established evidence in favor of the monetary model in the very long term, especially in terms of forecasting, but concluded that the model has both low explanatory and predictive powers at shorter horizons. Khalid [12] studied the predictability of the exchange rate models for developing countries like China, India and Pakistan and highlighted that the monetary model based on macroeconomic fundamentals works best for the developing countries, which is a significant deviation from existing research findings that consider random walk to be better performing.

Having conducted the review of literature, we observed that while there exists substantial research on modelling exchange rate for advanced countries, studies based on emerging economies especially India are extremely few. In the Indian context, the study conducted by Dua and Ranjan [13] is noteworthy which examines the fore- 
casting ability of economic models with respect to Indian rupee vis-à-vis US dollar. The study covered the period starting from July 1996 till December 2006. The out-of-sample forecasting was conducted for the period January 2007 to January 2008. The study found that monetary model performs better than the random model. Our study builds on the earlier research of Dua and Ranjan [13] spanning a longer period starting from August 1996 till March 2015 which is divided into sub periods based on the variations in exchange rate volatility. The present paper attempts to test the flexible price monetary model of exchange rate determination for Indian Rupee vis-à-vis US dollar.

\section{Theoretical Framework}

This section details the flexible price monetary model (Frenkel [3]; Mussa [14]) which provides the theoretical foundations of the study. The model deals with money market, goods market and asset market equilibrium. The model begins with money market equilibrium where exchange rate is a price of relative monies in two countries.

The money market equilibrium in the home country is given as:

$$
M / P=L(Y, i)
$$

after taking log both the sides, we get,

$$
\begin{gathered}
m_{t}-p_{t}=-\eta i_{t}+\phi y_{t} \\
m_{t}=p_{t}-\eta i_{t}+\phi y_{t}
\end{gathered}
$$

We can derive money market equilibrium in foreign country as

$$
\begin{aligned}
& m_{t}^{*}-p_{t}^{*}=-\eta^{*} i_{t}^{*}+\phi^{*} y_{t}^{*} \\
& m_{t}^{*}=p_{t}^{*}-\eta^{*} i_{t}^{*}+\phi^{*} y_{t}^{*}
\end{aligned}
$$

All the variables are in natural log.

where $e=$ price of foreign currency in domestic currency

$m=$ money supply

$m^{*}=$ money supply in foreign country

$y=$ real output

$y^{*}=$ real output in foreign country

$i=$ nominal interest rate.

$t$ represents time, $\eta$ and $\varphi$ are positive constants of home country and $\eta^{*}$ and $\varphi^{*}$ are parameters of foreign country.

The flexible price monetary model was developed under the assumption of one good and perfect price flexibility. It implies Purchasing Power Parity (PPP) holds continuously. The goods market equilibrium thus is given as:

$$
s_{t}=p_{t}-p_{t}^{*}
$$

The next assumption of the model describes asset market condition. The model assumes perfect mobility of capital, i.e., the domestic and the foreign bonds are perfect substitute. It implies uncovered interest rate parity (UCIRP) which incorporates the expectation in the asset market due to uncertainty. It is given as:

$$
i_{t}=i_{t}^{*}+E_{t}\left(\Delta s_{t+1}\right)
$$

Money supply in the economy determines the price level in the home country and hence exchange rate is determined by the relative money supplies in two countries. We can further derive the model as follows:

Subtract Equation (5) from (4), we get:

$$
\left(m_{t}-m_{t}^{*}\right)=\left(p_{t}-p_{t}^{*}\right)-\left(\eta i_{t}-\eta^{*} i_{t}^{*}\right)+\left(\phi y_{t}-\phi^{*} y_{t}^{*}\right)
$$

Since monetary model assumes that Purchasing Power Parity (PPP) holds, we can write the above equation as

$$
s_{t}=\left(m_{t}-m_{t}^{*}\right)+\left(\eta i_{t}-\eta^{*} i_{t}^{*}\right)-\left(\phi y_{t}-\phi^{*} y_{t}^{*}\right)
$$


It is assumes that interest rate and income elasticities are identical hence $\left(\eta=\eta^{*}\right)$ and $\left(\phi=\phi^{*}\right)$. This indicates that the variables affect exchange rate in opposite direction but of same magnitude. By substituting $\left(\eta=\eta^{*}\right)$ and $\left(\phi=\phi^{*}\right)$, Equation (9) can be written as follows

$$
s_{t}=\left(m_{t}-m_{t}^{*}\right)+\eta\left(i_{t}-i_{t}^{*}\right)-\phi\left(y_{t}-y_{t}^{*}\right)
$$

Equation (10) is the Flexible Price Monetary Model (FPM) which indicates that; if domestic money supply increases relative to foreign money supply, value of $S_{t}$ will increase indicating depreciation of domestic currency against foreign currency. Conversely, a boost in domestic real income, ceteris paribus, creates an excess demand for the domestic money stock. In an attempt to increase their real money balances, domestic residents reduce expenditure and prices fall until money market equilibrium is achieved. Via PPP, the fall in domestic prices (with foreign prices constant) implies an appreciation of the domestic currency in terms of the foreign currency (a rise in the value of domestic currency in terms of foreign currency) (Neely and Sarno [15]).

\section{Data Sources and Methodology}

The study is based on secondary data for India and the United States. Monthly data from August 1996 to March 2015 is being considered for the study. Though India adopted managed floating exchange rate regime since March 1993, our sample period starts from August 1996 due to the availability of the data for all the series. Index of Industrial Production (IIP) has been taken as proxy to output since estimates of GDP are available only quarterly. The data for exchange rate, money supply and interest rates (91-days Treasury Bill rate) for India is collected from the database of Indian economy by Reserve Bank of India. The source of IIP for India is Ministry of Statistics and Program Implementation. The data for US money supply, IIP, and interest rate (3-month Treasury Bill rate) is collected from Board of Governors of the Federal Reserve System, US (Table 1).

\subsection{Methodology}

The data in the model conforms to time series data. To establish the model, it is important to test the variables for stationarity. One of the assumptions of classical linear regression model is that the variables under study must be stationary. If they are non stationary, regression model becomes "spurious" despite high value of R-squared. The following section analyzes the long-run relationship among money, output interest rates and the exchange rate for the whole sample (August 1996 to March 2015).

\subsection{Analysis of Full Sample Period (August 1996 to March 2015)}

The full period starts from August 1996 till March 2015. The Indian rupee fluctuated in a wide range against US dollar during this period. The minimum was Rs. 35.7/\$ and maximum of Rs. 66.6/\$ with the standard deviation of 6.6. The high value of standard deviation indicates high volatility especially after the crisis (2009) (see Table 2).

The following diagnostic tests were undertaken to test the stationarity of the data.

1. Augmented Dickey Fuller (ADF) test,

2. Phillips and Perron (PP) test, and

3. Kwiatkowski, Phillips, Schmidt, and Shin (KPSS) test.

\section{Table 1. Sources of data.}

\begin{tabular}{ccc}
\hline \multicolumn{1}{|c}{ Variables } & Data Source for India & Data Source for the US \\
\hline Exchange rate INR/USD & Board of Governors of the & Federal Reserve System, US \\
Money supply & Database on Indian Economy by RBI & Board of Governors of the \\
Federal Reserve System, US & Board of Governors of the \\
91-days treasury bill rate & Dederal Reserve System, US & Board of Governors of the \\
IIP & Federal Reserve System, US & Ministry of Statistics and Program Implementation
\end{tabular}


Table 2. Indian Rupee/US Dollar for different period.

\begin{tabular}{ccccc}
\hline Period & Mean & Standard Deviation & Minimum & Maximum \\
\hline August 1996 to March 2015 & 47.0 & 6.6 & 35.7 & 66.6 \\
August 1996 to Feb 2008 & 43.7 & 3.6 & 35.7 & 49.0 \\
March 2008 to March 2015 & 52.4 & 6.8 & 42.5 & 66.6 \\
\hline
\end{tabular}

\subsection{Unit Root Test}

To test whether the variables under consideration were stationary, three diagnostic tests were administered. They are ADF test (Dickey \& Fuller, [16]), PP test (Phillips and Perron, [17]) and KPSS test (Kwiatkowski, Phillips, Schmidt, and Shin, [18]). ADF and PP test defines null hypothesis to be existence of unit root while KPSS test defines null hypothesis to be stationary. Testing for contrast null hypothesis will lead to better decision making. If two out of three tests indicate that the variable is non-stationary, we will consider that the series has unit root. The unit root test results are reported in Table 3.

All the variables were found to be non-stationary at levels but stationary at first difference. Thus we can infer that the variables under study are integrated of order one I (1).

\subsection{Cointegration Test}

To test for cointegration, Johansen Juselius [19] technique was applied. Cointegration checks if model reveals meaningful empirical relationship. If the variables are of non-stationary at level and residual of the model is stationary, that means there exist cointegration. The condition for testing of cointegration is that the series must be integrated of same order. Since unit root rest conducted in our model revealed that the series are integrated of order one, hence we conducted Johansen Juselius test of cointegration. If two variables are non-stationary at levels but the residual is stationary, it indicates that they have common stochastic trend. The results of cointegration rank test (Trace and Maximum Eigen-value) for the full period is reported in Table 4 and Table 5.

The result confirms that there exists cointegration and hence we can infer that the series have common stochastic trend. This implies that in the long-run, monetary model explains the exchange rate behavior regardless of the direction of causality (Garces-Diaz [20]). The co-efficient of the lagged error-correction term indicates the speed of convergence to equilibrium. It implies that the deviation from the equilibrium level of exchange rate during the current period will be corrected in the next period. It supports the monetary model in explaining behavior of exchange rate during the period under study. The results are in line with the previous studies in the Indian context such as Shylajan, Sreejesh, \& Suresh [21] and Dua and Ranjan [13].

\subsection{Analysis of Sub-Periods}

\subsubsection{Analysis of Sub-Periods (August 1996 to February 2008)}

The current study divides the period of study into two sub-periods. The initial period starts from August 1996 till Feb 2008 before the global crisis during which the Indian rupee was quite stable against US dollar. The Indian rupee fluctuated between Rs. 35.7/\$ and Rs. 49.0/\$ against US dollar for the period before crisis. The standard deviation during this period was 3.6 indicating stable exchange rates (refer Table 2).

\subsubsection{Analysis of Sub-Periods (March 2008 to March 2015)}

The second period commences with the onset of the global crisis. This period witnessed high volatility of exchange rate. Indian rupee fluctuated between Rs. 42.5/\$ and Rs. 66.6/\$. The standard deviation was 6.8 indicating high volatility. The results of Granger causality test for this period is reported in Table 7.

\subsection{Granger Causality Test}

Having established the existence of cointegration, causality in the Granger (temporal) sense must exist in at least one direction [22]. Granger causality test [22] was conducted to determine the direction of causality between variables and to evaluate the predictive power of the model. The standard Granger Causality test with a lagged error-correction term is applied if the series are cointegrated. The result of the direction of causality between variables for the sub-periods is reported in Table 6 and Table 7. 
Table 3. Unit root test (full period).

\begin{tabular}{ccccc}
\hline & ADF & PP & KPSS & Decision \\
\hline $\mathbf{e}$ & $\mathrm{I}(1)$ & $\mathrm{I}(1)$ & $\mathrm{I}(1)$ & $\mathrm{I}(1)$ \\
$\left(\mathbf{m}-\mathbf{m}^{*}\right)$ & $\mathrm{I}(1)$ & $\mathrm{I}(1)$ & $\mathrm{I}(1)$ & $\mathrm{I}(1)$ \\
$\left(\mathbf{y}-\mathbf{y}^{*}\right)$ & $\mathrm{I}(0)$ & $\mathrm{I}(1)$ & $\mathrm{I}(1)$ & $\mathrm{I}(1)$ \\
$\left(\mathbf{i}-\mathbf{i}^{*}\right)$ & $\mathrm{I}(1)$ & $\mathrm{I}(1)$ & $\mathrm{I}(1)$ & $\mathrm{I}(1)$ \\
\hline
\end{tabular}

Table 4. Unrestricted cointegration rank test (trace).

\begin{tabular}{ccccc}
\hline Hypothesized & & & Trace & \multicolumn{1}{c}{$\mathbf{0 . 0 5}$} \\
\hline No. of CE(s) & Eigen-Value & Statistic & Critical Value & Prob. $^{* *}$ \\
None $*$ & 0.125659 & 65.98565 & 47.85613 & 0.0004 \\
At most 1 * & 0.10747 & 35.90587 & 29.79707 & 0.0087 \\
At most 2 & 0.034599 & 10.4381 & 15.49471 & 0.2485 \\
At most 3 & 0.011323 & 2.550755 & 3.841466 & 0.1102 \\
\hline
\end{tabular}

Table 5. Unrestricted cointegration rank test (maximum eigen-value).

\begin{tabular}{ccccc}
\hline Hypothesized & & & Max-Eigen & $\mathbf{0 . 0 5}$ \\
\hline No. of CE(s) & Eigen-value & Statistic & Critical Value & Prob. $^{* *}$ \\
None * & 0.125659 & 30.07978 & 27.58434 & 0.0234 \\
At most 1 * & 0.10747 & 25.46777 & 21.13162 & 0.0115 \\
At most 2 & 0.034599 & 7.887343 & 14.2646 & 0.3902 \\
At most 3 & 0.011323 & 2.550755 & 3.841466 & 0.1102 \\
\hline
\end{tabular}

Table 6. Granger causality test during August 1996 to February 2008 (period before crisis).

\begin{tabular}{|c|c|c|c|c|}
\hline Null Hypothesis & No. of Lags & F Statistic & P-value & Decision \\
\hline e does not Granger caused by $\left(y-y^{*}\right)$ & 2 & 5.01759 & 0.0079 & Reject Ho \\
\hline e does not Granger caused by (m-m*) & 2 & 2.40288 & 0.0943 & Reject Ho \\
\hline e does not Granger caused by (i-i*) & 2 & 0.01946 & 0.9807 & Do not Reject \\
\hline
\end{tabular}

Table 7. Granger causality test during March 2008 to March 2015 (period of crisis).

\begin{tabular}{|c|c|c|c|c|}
\hline Null Hypothesis & No. of Lags & F Statistic & P-value & Decision \\
\hline e does not Granger caused by $(y-*)$ & 2 & 0.031 & 0.9695 & Do not Reject \\
\hline e does not Granger caused by (m-m*) & 2 & 0.1361 & 0.8729 & Do not Reject \\
\hline e does not Granger caused by $\left(\mathbf{i}-i^{*}\right)$ & 2 & 3.6947 & 0.0292 & Reject Ho \\
\hline
\end{tabular}

The Granger causality test results shows that there is one-way causality from relative output and relative money supply to exchange rate, however there is no causality from relative interest rate to exchange rates. While relative money supply and relative output conforms to the theory, relative interest rates provide contrary results. This result is quite puzzling and calls for further investigation. The plausible reason can be associated with the sample period selected for this study. To maintain economic growth at sustainable level, Federal Reserve of US adopted steady decline in interest rates. Federal Fund rates were declined from 6.5\% in Jan 2001 to $1 \%$ by June 
2003. This period was a low interest rate period in the US. The decline in foreign interest rates usually leads to the depreciation of the foreign currency and appreciation of the domestic currency. Decline in the U.S. interest rates did not prove detrimental for Indian rupee as the nominal exchange rate (Indian rupee) was adjusted by virtue of the intervention of the Reserve Bank of India.

The Granger Causality test for the second period revealed a switch in direction of causality among the variables when compared to the initial sub period. During the second sub period there was one-way causality from relative interest rates to exchange rate, however relative money supply and relative output did not Granger cause the exchange rate. It is suggested that the mixed results could be an outcome of the financial crisis and the subsequent recovery when both the central banks resorted to an expansionary monetary policy resulting in the breakdown of relationship among the macroeconomic fundamentals.

The results indicate meaningful long-run relationship between exchange rate and monetary model variables for Indian Rupee against the US dollar. The switch in the direction of causality across the sub periods inferred that the predictive ability of monetary model in the long run is weak.

\section{Conclusions}

In this paper, the empirical relevance of the flexible price monetary model has been studied for India, to determine whether US dollar-Indian rupee exchange rate movements are in line with the changes in monetary fundamentals. Flexible price monetary variables namely relative money supply, relative interest rates and relative output were considered in the study. A sample period of nineteen years (August 1996 to March 2015) was considered for the study and the entire period was divided into two sub periods marked by distinct patterns of exchange rate volatility and variations in the behavior of macro-economic fundamentals. The initial period (August 1996 to February 2008) represents the post-reforms period in India and exchange rate was quite stable while during the second sub-period, exchange rate turned out to be very volatile owing to the global economic crisis resulting in the breakdown of the relationship among the macroeconomic fundamentals. The study therefore examined, first, whether there exists a long-term relationship between exchange rate and variables of the monetary model. Second, it investigates the predictive ability of the monetary model in determining the exchange rate in the Indian context.

The cointegration analysis was carried out using the Johansen Juselius test of cointegration and the variables were found to be linearly cointegrated establishing the long-run relationship between exchange rate and monetary fundamentals namely relative money supply, relative output and relative interest rate thereby confirming the suitability of the flexible price monetary model in determining Indian rupee vis-à-vis US dollar. Granger causality test was conducted to determine the direction of causality between variables and to evaluate the predictive power of the monetary model. Interestingly, the test exhibited some idiosyncratic patterns among the variables across the two sub-periods. For the first sub-period, the Granger causality test results show that there is a oneway causality from relative output and relative money supply to exchange rate, while there is no causality from relative interest rate to exchange rates. The Granger causality test for the second period revealed a switch in direction of causality among the variables when compared to the initial sub-period. During the second sub-period there was one-way causality from interest rates to exchange rate; however relative money supply and relative output did not cause the exchange rate. It is suggested that the mixed results could be an outcome of the financial crisis and the subsequent recovery when both the central banks resorted to an expansionary monetary policy resulting in the breakdown of relationship among the macroeconomic fundamentals.

As the direction of causality is changing within the sample, it may be concluded that the monetary model standalone cannot be effectively used for predicting exchange rate in the Indian context. A more comprehensive model with more macro economic variables such as trade balance and capital flows may be combined with the existing variables of the current study. The microstructure model and intervention by the central bank may also be considered for effective forecasting of exchange rate in India.

\section{References}

[1] Evans, M.D.D. and Lyons, R.K. (2001) Why Order Flow Explains Exchange Rates. NBER, USA.

[2] Evans, M.D.D. and Lyons, R.K. (2007) How Is Macro News Transmitted to Exchange Rates? NBER, USA.

[3] Frenkel, J.A. (1976) A Monetary Approach to the Exchange Rate: Doctrinal Aspects and Empirical Evidence. The Scandinavian Journal of Economics, 78, 200-224. http://dx.doi.org/10.2307/3439924 
[4] Dornbusch, R. (1976) Expectations and Exchange Rate Dynamics. The Journal of Political Economy, 84, 1161-1176. http://dx.doi.org/10.1086/260506

[5] Meese, R.A. and Rogoff, K. (1983) Empirical Exchange Rate Models of the Seventies: Do They Fit out of Sample? Journal of International Economics, 14, 3. http://dx.doi.org/10.1016/0022-1996(83)90017-X

[6] Mark, N.C. and Sul, D. (2001) Nominal Exchange Rates and Monetary Fundamentals Evidence from a Small PostBretton Woods Panel. Journal of International Economics, 53, 29-52. http://dx.doi.org/10.1016/S0022-1996(00)00052-0

[7] Zhang, S., Lowinger, T.C. and Tang, J. (2007) The Monetary Exchange Rate Model: Long-Run, Short-Run, and Forecasting Performance. Journal of Economic Integration, 22, 397-406. http://dx.doi.org/10.11130/jei.2007.22.2.397

[8] Abhyankara, A., Sarno, L. and Valenteb, G. (2005) Exchange Rates and Fundamentals: Evidence on the Economic Value of Predictability. Journal of International Economics, 66, 325-348. http://dx.doi.org/10.1016/j.jinteco.2004.09.003

[9] Alao, R.O., Oziegbe, T.R., Ibidapo, C.O.K. and Sharimakin, A. (2011) The Flex Price Monetary Model of the DollarNaira Exchange Rate Determination: A Cointegration Approach. British Journal of Arts and Social Sciences, 2, 21-33.

[10] Olaniyi, E. (2013) The Monetary Model of Exchange Rate in Nigeria: An Autoregressive Distributed Lag (ARDL) Approach. MPRA Paper No. 52457.

[11] Bruyn, R., Gupta, R. and Stander, L. (2013) Testing the Monetary Model for Exchange Rate Determination in South Africa: Evidence from 101 Years of Data. Vizja Press \& IT, 7, 19-32.

[12] Khalid, S.M.A. (2008) Empirical Exchange Rate Models for Developing Economies: A Study on Pakistan, China and India, Electronic Copy. http://dx.doi.org/10.2139/ssrn.1097638

[13] Dua, P. and Ranjan, R. (2011) Modelling and Forecasting the Indian Re/US Dollar Exchange Rate. Centre for Development Economics, Delhi School of Economics Working Paper, 197.

[14] Mussa, M.L. (1976) The Exchange Rate, the Balance of Payments and Monetary and Fiscal Policy under a Regime of Controlled Floating. The Scandinavian Journal of Economics, 78, 229-248. http://dx.doi.org/10.2307/3439926

[15] Neely, C.J. and Sarno, L. (2002) How Well Do Monetary Fundamentals Forecast Exchange Rates? Review-Federal Reserve Bank of Saint Louis, 84, 51-74.

[16] Dickey, D.A. and Fuller, W.A. (1979) Distribution of the Estimators for Autoregressive Time Series with a Unit Root. Journal of the American Statistical Association, 74, 427-431.

[17] Peter, C., Phillips, B. and Perron, P. (1988) Testing for a Unit Root in Time Series Regression. Biometrika, 75, 335346. http://dx.doi.org/10.1093/biomet/75.2.335

[18] Kwiatkowski, D., Phillips, C.B., Schmidt, P. and Yongcheol, S. (1992) Testing the Null Hypothesis of Stationarity against the Alternative of a Unit Root. Journal of Econometrics, 54, 159-178. http://dx.doi.org/10.1016/0304-4076(92)90104-Y

[19] Johansen, S. and Juselius, K. (1990) Maximum Likelihood Estimation and Inference on Cointegration with Applications to the Demand for Money. Oxford Bulletin of Economics and Statistics, 52, 169-210. http://dx.doi.org/10.1111/j.1468-0084.1990.mp52002003.x

[20] Garces-Diaz, D. (2004) How Does the Monetary Model of Exchange Rate Determination Look When It Really Works? Econometric Society North American Winter Meetings, Vol. 60, San Diego, 3-5 January 2004.

[21] Shylajan, C.S., Sreejesh, S. and Suresh, K.G. (2011) Rupee-Dollar Exchange Rate and Macroeconomic Fundamentals: An Empirical Analysis Using Flexible-Price Monetary Model. Journal of International Business and Economy, 12, 89105.

[22] Granger, C.W.J. (1986) Developments in the Study of Cointegrated Variables. Oxford Bulletin of Economics and Statistics, 48, 213-228. http://dx.doi.org/10.1111/j.1468-0084.1986.mp48003002.x 